\title{
FROM MODERN ROCK TO POSTMODERN HARD ROCK: CAMBODIAN ALTERNATIVE MUSIC VOICES
}

\author{
LinDa Saphan \\ College of Mount Saint Vincent
}

Music is the most abstract of all art forms. It is also a flexible art form subject to many influences and appropriation of different artists, genres, and cultures. Yet when it comes to Cambodian music-especially contemporary genres - one theme predominates for the audience: authentic music. Some commentators remark that contemporary Cambodian music consists merely of appropriation of foreign music, in contrast to the prewar musicians who performed an authentic musical repertoire. But as Butt argues, by definition music has no borders and is pluralistic in sound: "Music ceases to be that hermetically-sealed object existing apart from our everyday concerns, and becomes instead a line, an infinitely-expanding polyphony of cultural practice" (Butt 2006, 11). We will not linger on defining the concept of authenticity or even attempt to attach it to any form of nationalism. Music that Cambodian artists have crafted and are still crafting reflects pluralistic practices extending beyond national territories.

In Cambodia, the performing arts, particularly music, are important forms of sociocultural discourse. In the ethnomusicological tradition of Cambodia, there are many accounts of the people's joy, despair, and heroic action glorified by storytellers and expressed through traditional performance genres. Musical performance in Cambodia serves not only to accompany religious rituals and convey cultural messages, but also to convey the political message of each regime and each generation's selfexpression.

Before rock and roll came to Cambodia, there was already a strong musical presence and lively popular music scene. Popular music emerged from the Mohori ensemble because this is the only ensemble that does not have a religious function or serve to accompany another art form (Sam Ang-Sam, interview, 2009). Popular music was created specifically for entertainment by mixing the traditional music of the Mohori with new melodies and rhythms. Already a popular musical form, Mohori expanded its repertoire and genres to reach a wider and younger audience in the city and countryside alike. Rural people called the new form "jazz" or "stepping music" after the prominence of drums (Keo 2004, 96). 
These modern rhythms were popular in dancehalls and restaurants, where it was possible to dance to traditional songs with dances such as the Roam Vong, Roam Kbach, Roam Saravann, and later the Madison.

Modernity in Cambodia was an affair of the state: musicians embraced Sihanouk's plan for modernizing the country, while today's songs reflect a pluralistic postmodern society and the diverse voices of globalized performers. This paper will compare modern and postmodern music and musical appropriation in the contemporary Cambodian alternative music scene. An overview of the popular, rock, and hip-hop music of Cambodian communities is beyond the scope of this article. I aim instead to shed some light on musical appropriation before the Khmer Rouge regime and today's alternative voices by using the lens of modernity and postmodernity as analytical tools to understand music voices. I will not judge the quality or authenticity of specific music, but will draw parallels between early rock and roll and today's hip-hop musical influences.

\section{One Voice of Modernity}

When Norodom Sihanouk gained independence for the country in 1953, the whole population was ready to enter the modern world by breaking its link with the colonial past. Cambodia embarked on a modernization process dominated by technological progress and a new national identity. Charles Jencks's definition of modernism traces back to Roman times and stresses the importance of the present time as a sense of progress: "The term ["modernism"] has carried a progressive impulse ever since, both technical and moral" (Jencks 2009, 20). Buildings sprouted all over Phnom Penh, symbolizing the new aesthetic age.

The modernization movement was not the work of a single individual as stated by architect Vann Molyvann in an interview (2004). American poet T. S. Eliot expressed this in his analysis of the modern poetry movement: "No poet, no artist of any art, has his complete meaning alone. His significance, his appreciation is the appreciation of his relation to the dead poets and artists" $(1982,37)$. However, modernization in Cambodia was first and foremost a top-down program of the state searching to appropriate modern designs, genres, styles, and plans to inject into the Cambodian landscape. Without the royal figure of Norodom Sihanouk, pre-Khmer Rouge development would have been quite different. He embraced modernization through agricultural and technological development and was himself the embodiment of the modern Khmer man.

Sihanouk's enthusiasm convinced the Cambodian people to embrace change. By promoting popular culture, Sihanouk gave legitimacy to artists, increasing their esteem in the eyes of the population. Unlike the French rulers, Sihanouk encouraged modern artistic practices. He truly 
loved Cambodia's traditional cultural heritage but also sought to open its doors to new modern genres.

Cambodian musical appropriation of the pre-Khmer Rouge era was intertwined with Sihanouk's political agenda. Music served the government by strengthening national unity and spreading modernity among the population. Early Cambodian rock and roll needs to be understood in this political and historical frame of reference. As Grossberg (2000) notes, "Rock and Roll is a cultural event that emerged at a particular moment into a particular context" (112). The emerging rock and roll played an important role in the political project of the newly independent country and its population seeking to become modern citizens. Cambodians were modern citizens as defined by Marshall Berman (1998), as embracing their present and feeling comfortable and at home in this new era of progress.

\section{Sihanouk: The Modern Man}

Sihanouk came from a family who loved music and took pride in their musical skills, providing him with a strong musical background. His father was a competent musician and his mother listened to modern French singers like Tino Rossi, Edith Piaf, and Charles Trenet. Once he took power, Sihanouk became an enthusiastic patron of the arts, but he was also an artist in his own right. He was a multitalented musician-he played the saxophone, piano, and other instruments - as well as a composer, singer, filmmaker, poet, actor, and interior designer.

Sihanouk understood the important role that music played for his people and he used that understanding to his political advantage. A modern band performed before and after each of political speeches. The Royal Military Orchestra accompanied him in all his travels about the country, ensuring a large crowd at every public event he attended and promoting his image as a popular leader. Sihanouk asked each ministry to have its own musical band - the ultimate sign of patronage and support for popular music. These bands performed all types of popular music, ensuring financial stability and social position for the performers. Sihanouk selected the most prominent talents to perform with his personal orchestra, including Ros Serey Sothea, Sin Sisamouth, and Sos Mat. With the rock group Baksei Chamkrung Band a new musical trend, the electric guitar band influenced by Cliff Richards, was discovered and Sihanouk immediately invited the band to perform for him. Prominent female singers Mao Sareth, Chhuon Malay, and Sieng Di worked with the Royal Military Orchestra. They were the very first generation of female singers to perform both traditional and modern music and to produce vinyl records. They sang songs about the provinces and cities they 
visited, with titles like "Divine City of Medicine" (Kep City), "Summit of Bokor Mountain," and "Beautiful Mondulkiri Province."

Sihanouk's song 'Phnom Koulen,' most likely written in the 1950s, extols the Phnom Koulen mountain range in northwestern Cambodia:

Beyond the lush green jungle lands,

Beyond the sloping valley,

Stands the golden mountain

Majestic symbol

Of a time flown by,

Proud and haughty watcher

That judges from on high.

Oh! Phnom Koulen

Let your old wisdom

Guide our young ways

Giving strength

To meet future days.

\section{Mountain,}

Guard thy country, guard its rich earth,

Guard the place of thy birth.

(http://norodomsihanouk.info/document/doc_2197.html)

This song embodies Sihanouk's vision of Cambodian culture as an old civilization rich in traditional art forms yet seeking broader horizons for new endeavors. It celebrates the cultural heritage while encouraging the audience to embrace new foreign influences in the Cambodian landscape. This song reassured the old guard of their value but spoke to youth about the possibilities ahead of them. Similar to his political neutrality during the regional Cold War, Sihanouk attempts in this song to bridge the generation gap between old and young.

The love songs written early in his career as a composer reflect the country's emerging enthusiasm for joining Sihanouk's social and political modernization project. The political agenda of these songs is easily discernable. Sihanouk used these recorded songs broadcast on the radio as a means of reaching out to the Cambodian people to encourage them to celebrate his goal of establishing a modern country under his leadership.

The pre-Khmer rouge era was idealized as the "Golden Era" and Phnom Penh as the "Pearl of Southeast Asia." Sihanouk was able to build prosperity, maintain stability, and avoid war through a policy of neutrality during the Cold War precipitated by the support of Cambodian and North Vietnamese communists by the Soviet Union and China. But these benefits were achieved through Sihanouk's authoritarianism and came at a cost: there was no political freedom of expression, and mem- 
bers of the Communist Party were executed as traitors who undermined the peace and political stability of the country. For Cambodians who supported democracy and free speech, the moniker "Golden Era" did not reflect the political reality of the time.

Sihanouk's modernization program provided a social context for musicians to thrive, creating new sounds and experimenting in new musical territory. Having the head of the government supporting and playing modern music himself gave it social value among the population. Without Norodom Sihanouk's love for music, there certainly would not have been such a thriving scene then.

As expected, the new songs celebrated the nation's modernization. There were no songs protesting political or social conditions as in Western popular music of the same era. The rock and roll bands that played at Sihanouk's speeches were there to bolster his political image as a popular and charismatic leader, while his own songs celebrated the country's beauty or supported his agenda in international relations.

\section{The Rocker: Urban Bourgeois Youth}

Despite the many changing political regimes in Cambodia in a short period of time following independence, there were still only two social classes in the country: the urban dweller and the villager, with two distinct life styles and means of accessing modernity and music. Traditional music seemed to follow that division: one style practiced at the royal palace, and the other in the villages. Rural Cambodians accessed music mainly through the national radio, while urban dwellers had more options, such as records from foreign countries. With the emerging popular culture, a third social category became relevant to shaping and promoting the new musical form: the urban bourgeoisie. While many musicians were from the provinces, Phnom Penh became the hub for a subculture of innovative musical genres. In the capital city, expanded career opportunities opened up in the music industry working for recording companies, performing in clubs, and playing for big-band orchestras in ministries and private bands. Unlike folk musicians in the villages, the new urban musicians performed a wide repertoire from traditional folk songs to rock and roll tunes.

As with Sihanouk's authoritarian political regime, the popular music scene was shaped from the top down, by the urban bourgeoisie. The first generation of popular singers from the 1950s to the early 1960s came from various social backgrounds-Ros Serey Sothea was a farm girl while Sin Sisamouth came from a middle-class provincial familybut all were professionally trained. The rockers came from the uppermiddle to the elite class. They had no professional training but had a 
passion for music and the financial means to acquire needed instruments and equipment.

Peter Manual reminds us that "modernity has often been identified with the Enlightenment and Euro-American bourgeois culture" (1995, 228). Cambodian modernity followed the Euro-American path of being led by the bourgeoisie. The emergence of rock and roll began with the urban elite, who were able to send their children abroad for studies or leisure travel and could afford cultural materials such as magazines and records, as well as musical instruments, microphones, amplifiers, and so on to form music bands. Mol Kagmol from the band Baksei Chamkrung recounted that a guitar and a microphone cost the same as two motorcycles at that time (interview, 2009).

In the 1950s and 1960s very few Cambodians could afford a record player or even records. Panabou, located near the Central Market, opened in the early 1960s and was the first record store in Phnom Penh. Later many more stores offered electric guitars, such as Magasin D'Etat, which also had a concert hall. Music fans could order any records from their catalog or that they found on top-hit lists in magazines-but only the bourgeoisie class could afford to do so. Some musicians needed to save carefully to buy the latest hit songs, while others had friends or family who could bring records back directly from France or neighboring countries.

Musicians performed at nightclubs, restaurant bars, private parties, and universities-all frequented by urban bourgeoisie youth. For most Cambodians, the radio was their only means of listening to the latest songs. However, the national radio was bound by rules and conventions: foreign-language songs were banned except for special programs broadcast through international cooperation. The richest families could afford to hire a band for a birthday party or embassy celebrations.

Traditionally a career in music was handed down through families from one generation to the next. Later, singers sought opportunities for social mobility through their skills, for example by participating in singing contests. For them, the music industry meant a career and an income, as depicted in the Cambodian film Pheakdey, produced in 1973 by Ivon Hem and starring Vichara Dany, in which a young girl is offered a record deal in the city and gains financial stability and recognition.

With the birth of true rock and roll, music took on new purposes for leisure and self-expression. The new musicians and singers came from the middle- and upper-class families of Phnom Penh. The Mol brothers, Kagmol and Kagmach, who started the first guitar band in the 1960s, Baksei Chamkrung, came from one of the wealthiest family in Phnom Penh. Prince Sisowath Panara Sirivudh played with the band Apsara and 
while prince Norodom Sirivudh, half brother of Norodom Sihanouk, supported musicians materially.

Without the urban bourgeoisie youth of Phnom Penh possessing the desire, wealth, and leisure time to create music, there would have been no opportunity for modern popular music, and even less rock and roll, to flourish. Urban youth sought a new musical genre to identify with and to express themselves in this era of modernization and opening of the country to the rest of the world. The Mol brothers, for example, were not professional musicians; they performed for free and would not accept money for their services. Their parents tolerated their "hobby" as long as it did not interfere with their studies. Thus popular music was a class interest. Only the elite had access to the new music and they became agents of change, spreading musical influences and establishing patterns and networks of cultural exchange between Southeast Asia (and Sri Lanka) and Europe.

\section{The Modern Male Voice}

Modernity was originally a male concern, as Marshall Berman shows in his analysis of modernity in Goethe's Faust (1998), and Cambodia was no exception. While modern Cambodian music emerged from the urban class, the voice of music was mainly male and the music industry was dominated by men. Songwriters of the time were exclusively male, among them Pov Sipor, Mer Bun, Sin Sisamouth, Kung Van Choeun, Has Salon, Voy Ho, Malapi, Ouk Sinareth, and Samneang Rithy. Even when the singers were women and sang about women, the composer was always male. There was a clear gender-based division of labor in the music industry, and female performers singers did not write lyrics or music.

Singer Sieng Di recalled in an interview (2009) that the male singer and song writer Sin Sisamouth wrote a love song for her to sing called "Pruos te Srolan" (Because of Love). The song expressed Sieng Di's husband's devotion to her, but as seen through the eyes of the male composer. As a woman there was no precedent for her to tell her own love story by composing the song herself. Sin Chann Chaya, Sin Sisamouth's son, said that his father took time each day to listen to people's life stories and wrote songs based on them. Thus postcolonial-era popular and rock and roll music had a decidedly male flavor. The famous song by Oum Dora, "Stop Loving Me," sung by Ros Serey Sothea, is an example of a melodramatic song about forsaken love that made the hit parade with its obvious Latin rhythm influence. Sothea was accompanied by an acoustic guitar played in a flamenco style. In this song she asks her lover to stop loving her since they can't get along and have no freedom. The 
musical repertoire sung by female singers of the time reflects a male perception of love and despair.

Some women were hired as lead singers for swing-style big bands such as the Ministry of Information and the Military band. Singers Ros Serey Sothea, Pen Ron, and Huy Meas worked for the National Radio while Sieng Di had a contract with the SKD Brewery band. These bands played a traditional repertoire mixed with jazz and Western popular music influences. Rock and roll bands such as Baksei, Bayon, Apsara, Drakkar, Garuda, Amara, and Sakira were all male. Unlike other neighboring countries such as Indonesia that had all-girl bands like Dara Pusita, Cambodia had no all-girl band playing popular or rock and roll music.

In the pre-Khmer Rouge era, rock and roll and hard rock were subculture phenomena, heard only by university students, urban residents, and people who had connections to embassies. Today the music of artists whose recordings - if they even recorded - survived the Khmer Rouge regime is no longer considered subculture, but popular music and part of the Cambodian collective memory.

Early rock and roll musicians were inspired by Western popular artists from France and later from the United States and Britain, such as the Beatles and Cliff Richards. Their music was not merely an imitation of the Western sources - they produced an original modern Khmer sound that later proved to be accessible to Western audiences. The Mol brothers' Baksei Chamkrung, with three guitarists, a drummer, and a lead singer, was the first band to combine different elements of Western rock. The band's style was influenced by the British movie The Young Ones (1961) starring Cliff Richards and the Shadows along with the Ventures. They played everything from rock and roll to Latin styles like rumba and bolero, adding their own original style to the Western genres. "What we did with Baksei Chamkrung was, we added the bass line, the power chord, and the solo part. And that breaks away from traditional Khmer music," Mol Kagmach reported in an interview (2010).

After Baksei, rock bands sprouted all over Phnom Penh in the early 1970s, most notably Apsara, Bayon, Amara, Gadura, Sakira, and Drakkar. Apsara with its lead singer Panara Sirivudh, took its inspiration mainly from Anglo-Saxon songs, with obvious influences from Little Richard, the Beatles, the Rolling Stones, and the Beach Boys. The band kept the melodies and translated the songs into Khmer. Other bands also did Apsara cover versions of Western songs. Bayon, founded by Hong brothers Samley, Sambath, and Samloth, covered many genres from the Kinks and the Platters to French rocker Johnny Hallyday. In the early 1970s their repertoire expanded to the Bee Gees and Santana. Performing at nightclubs, weddings, and parties, they sang songs in the original English, which they learned phonetically from album covers and radio 
broadcasts from the U.S. Navy's 7th fleet stationed in the South China Sea. Samley Hong stated that his greatest successes were his interpretations of Johnny Hallyday ("Souvenirs, Souvenirs") and Elvis Presley ("Blue Suede Shoes" and "Love Me Tender"). After Bayon, the band Drakkar brought a whole new sound to the 1970s with percussion, including bongos, added to the guitars and Santana as their main influence.

\section{Today's Postmodern Voices}

The term "postmodernity" points to its predecessor, modernity, but postmodernity is the outcome not only of modernity, but according to Giddens (1991) of globalization. Harvey (1990) suggested that the world had entered a new era since the 1970s with the development of new technologies that shifted societies from modern to postmodern. Jencks (2009) highlights a major difference between modernism and postmodernism: "Post-Modernism is a social style of the arts and Modernism an elite style" (24). In the postmodern era, the Internet and social media have intensified the spread of cultural influences around the globe and increased consumption and production of music across a broader spectrum of people. The Cambodian music scene is no longer reserved only for a bourgeois urban elite but can now be accessed by workingclass and marginal people, making room for more diverse and alternative voices heard through songs they write themselves. Contemporary Cambodian music encompasses an eclectic variety of musical genres and influences from many cultures.

The boundary between modernism and postmodernism in Western countries is quite blurred. It is clearer in Cambodia, where the Khmer Rouge regime created a sharper divide between the two. In the West, the Punk movement developed as a protest against the apathy of rock and roll, as noted by Grossberg (2000): "Punk emerged at, and responded to, a particular moment in the history of rock and roll. It is, after all, not coincidental that in 1976 the first baby boomers were turning thirty. Punk attacked rock and roll for having grown old and fat, for having lost that which puts it in touch with its audience and outside of the hegemonic reality" (117). In Cambodia, there was no opposition to the previous musical styles due to the disruption of culture by the Khmer Rouge and lack of awareness of the Cambodian rock scene of the 1960s and 1970s. As a result, the Cambodian subculture music scene today has little connection with the past.

\section{Alternative Female Voices}

Contemporary Cambodian musical voices are marked by pluralism. Women singers are composing their own songs, factory workers are singing about their hardship and working conditions, and political singers 
and protest songs are now part of the musical landscape. The first Cambodian all-girl band, the Messenger Band, was founded in 2005 by seven garment-factory workers. Their Facebook webpage describes them as a folk group with a social message: "As a grassroots advocacy group, their mission is to compose and perform original songs that reflect the current problems and situation face[d] by the working class and impoverished people of Cambodia."

In the 1970s, Yol Aularaing and Meas Samon were the only singers and songwriters who were making social commentary through their songs. The former used irony to comment on Cambodia's bourgeois conformist society and the latter used humor to draw attention to social conventions around relationships. But in the pre-Khmer Rouge era political and protest singers in the Western sense were unknown until the Messenger Band began giving a voice to the voiceless in Cambodian society, especially to other factory workers as well as sex workers. Their moving song "Land and Life" depicts the impact of forced evictions of people from their ancestral lands to make way for development. These are very brave women to tackle such an inflammatory political issue in a country where women have been jailed for protesting against forced evictions. Under Norodom Sihanouk's leadership there was little of freedom of speech. Compared to the 1960s and 1970s, with today's mass media, political protest messages can be sent around the world quickly, easily, and cheaply. The Messenger Band offers an alternative view of social reality that was previously unheard of on the popular music scene.

Postmodern music presents alternative voices not only in its musical genres, but also in its radically changed image and role of women. Sam Rocker, lead singer and songwriter for the alternative rock band No Forever, exemplifies this new freedom with her androgynous look. Both her appearance and her role as lead singer for an otherwise all-male hardcore band are beyond all conventional expectations of what a proper Cambodian young woman should be. In a music scene that is still very male dominated, she offers to her female audience an alternative femininity that frees them from social expectations around gendered fashion styles. She acknowledged her role and influence in an interview: "When I was young I did many bad things. . . . Now I write songs for people who were like me, and I want them to know that it is possible to stop destroying yourself and take your life in a more positive direction" (Thompson, n.d.)

Other women are following the same path, such as hip-hop singer Bochan Huy, Laura Mam, and Chhom Nimol from Dengue Fever, who is now cowriting songs with Zac Holtzman. The Messenger Band members write their own lyrics as well. 
Cambodian American hip-hop artist Bochan Huy undertook the challenge of revisiting the famous "I'm Sixteen," a modern rock song written by Voy Ho and sung by Ros Serey Sothea. The song has a definite Western rock influence, and its message is clearly about embracing the present and shying away from traditional themes, topics, and sounds. It was covered by many local Cambodians, and later it taken up by Dengue Fever with no alteration of lyrics or rhythm. Bochan Huy gave "I'm Sixteen" a postmodern twist in her original version, adding verses and changing the story about a young girl celebrating her sixteenth birthday to tell the story of the Cambodian diaspora's struggle for survival. Bochan's hip-hop interpretation changed the tone and the message from an innocent coming-of-age celebration to a feminist message of empowerment.

Bochan explains that in her recreated version of the familiar song, the lyrics play a crucial role, giving voice to her own experience as a female performer in a traditional society: "Ros Serey Sothea sings of a young woman coming of age and of her desires to explore and experience both the bitterness and sweetness of life freely. In the background, the men are singing and asking: 'Can I love you, Can I love you?' I interpreted the song to be one that empowers women greatly as she sings this in the face of a patriarchal society and in times where pre-arranged marriages were very common and expected" (personal correspondence, Feb. 27, 2014).

Bochan brings empowerment to her own music by being in control of her topics and lyrics as the songwriter. Increasingly, female singers today no longer require male songwriters to express their feelings and experiences. Like Bochan, many women musicians in the diaspora render a highly personal account of their life experience and stories in their songs. As Manuel (1995) explains, "The migrant's search for a sense of identity, like that of modernizing societies in general, is not necessarily a postmodern process, but one which synthesizes traditional and contemporary subjectivities in an often profoundly emotional manner" (235).

Why have hip-hop and rap been embraced in Cambodia and among the Cambodian subculture abroad, rather than other genres, like country and western? Cambodian youth in Cambodia and in the diaspora communities feel a discontinuity with the past. They are experiencing economic disparity, social marginalization, and alienation from their history--commonalities with the African American urban counterculture that gave rise to hip-hop and rap. The social message was at the heart of the birth of rap music. 


\section{Postmodern Rock Bands}

Today hard rock is growing rapidly in Cambodia. The alternative music scene is emerging among the youth culture in Phnom Penh, just as occurred with modern music in the 1960s, but this time musical voices are no longer confined to urban male bourgeois youth. The hard rock scene has a platform for new groups to perform at the Show Box in Phnom Penh, launched in 2012, which offers an alternative to not only Cambodian culture but also to the popular and dominant music scene, taking its major influence from K pop. A year before the Show Box opened, the deathcore group Sliten6ix came together to offer a different voice to the youth culture. The five members, all Cambodians, draw their influences from bands like Slipknot, Slayer, Suicide Silence, and Chelsea Grin. Sliten6ix's appropriation is mainly on the abstract level of musicality: the sound and their added cultural references are what matters. As Grossberg (2000) notes about rock and roll, "As many a rock and roll fan has commented, the power of the music lies not in what it says but what it does, in how it makes one move and feel" (112). This clearly applies to the heavy metal music scene emerging in Cambodia. In Sliten6ix's YouTube videos, it is difficult to distinguish the lyrics at all; only a few curse words can be heard. It is not the lyrics that are important, but how the audience receives their performance. In the videos the band as well as the audience are "headbanging" along with the music.

The year 2011 saw another alternative punk rock band formed: the ANTI-fate, who define themselves as pop punk and easy core. They can be seen as a continuation of the three-guitar tradition that Baksei Chamkrong started in the 1960s. They do cover versions of English songs by bands like Simple Plan (a Quebec rock group), Green Day (including their hit song "American Idiot"), Bowling For Soup, Blink 182 (unrelated to the Irish pop rock band Blink), the activist band Anti Flag, and Sum 41 (another Canadian rock group).

The most postmodern band from Cambodia would certainly be No Forever. Founded in 2012, it calls itself the first post-hardcore and metal band in Cambodia. Postmodernism is commonly defined as postmale, posturban, and postbourgeois, but here is a band that applies the prefix "post" to a musical genre. They do cover versions of groups like Asking Alexandria, Sleeping With Siren, Bring Me The Horizon, A Day to Remember, and the Prophecy.

As of this writing Cambodian hard rock bands are in an early stage of development, in which headbangers' sociocultural references, from clothing styles to cursing and dance movements, are imported from the West. Rogers (2006) describes four types of appropriation: cultural exchange (where reciprocal exchange occurs between cultures of equal power), cultural dominance (the imposition of dominate culture upon a 
subordinate one), cultural exploitation (the appropriation of a subordinate culture by a dominant one without any form of reciprocity), and transculturation (cultural elements crafted from multiples sources) (477). The Cambodian hard rock scene today is very much under the cultural dominance of Western hard rock, although Bochan demonstrates hybridity of both cultures intertwined in her version of "I'm Sixteen." Like Native American hip-hop described by Rogers, Cambodian American musicians embody transcultural hybrid music by localizing multiple cultural traditions.

\section{Youth Culture Past and Present}

The Cambodian music scene before the Khmer Rouge era was a small, close-knit community whose audience was also limited to a small group of urban youth. Rock and hard rock were then a subculture rather than mainstream genres. The subculture continues today for hip-hop, heavy metal, and hard rock music among the youth culture in Cambodia and abroad as mass media and affordable technologies now provide easy access to all kind of musical genres.

There is a parallel between today's youth subculture hard rockers and rock and rollers of the 1960s and 1970s: the resistance they encountered from the mainstream culture. Early Cambodian rock and roll was viewed quite negatively by the older generation of the time, just as hip hop, hard rock, and punk are viewed today. Part of the reason for the negative reaction was the new dance called the Twist that was associated with rock and roll. Singer Chum Kem went to Rome to study ceramics and on his return he brought back Chubby Checker's recording of "The Twist." In 1962 he planted the first seed of rock and roll in Cambodia with "Kampuchea Twist," a Khmer version of the American song. Supported by Sihanouk, Chum Kem was the first singer with a Western sound with Khmer lyrics to be broadcast on the radio. This inspired other musicians to seek new musical styles. But the new dance created quite a controversy, with elders proclaiming it should be forbidden.

Ly and Muan, in their book Cultures of Independence (2001), recount a debate among high school students at the Lycée Descartes and the adult reaction to the Twist. Some students defended the Twist as an art form and sport. Here is an example of the many letters about the Twist controversy that were published in school newspapers:

What hasn't been said about the twist? Its negative impact on dancers' muscular system has been criticized. After be-bop, the boogie-woogie, rock and roll, and the Canasta, now it's the Twist. . . . We don't laugh ourselves silly, we dance ourselves silly. It's intoxicating. 
We imitate the "original" sin. But the Twist looks more like the egotistical satisfaction of lonely people than the original sin. The couple twists separately on the dance floor without even touching each other. Is this some kind of tribute to solitary pleasure? At a time when speed is taking over human life, rhythm is also brought into step and conditioned by the syncopated tempo.

But the Twist is already passé. We're already talking about the "Swim." . . . Whether we twist or we crawl, humanity moves on. Hopefully they won't make us dance on a volcano or walk on our heads. Who knows, since gravity has been mastered? (Ly and Muan 2001, 210; my translation from French)

An article in the Phnom Penh Post (December 18, 2013) by Rom Molyka described how today's urban youth are striving to develop a rock scene. Veasna, lead guitarist for of the heavy metal band Sliten6ix, reported feeling misunderstood by the dominant culture: "People think that we are monsters-even the musicians and the listeners. They said why do you play this kind of music? It is useless. It doesn't earn you any money." A similar experience was shared by pre-Khmer Rouge musicians such as Touch Saly, former singer with the band Sonexim, founded in 1964 by the National Import and Export Company. Saly recounted in an interview that his parents and others told him he was wasting his youth on music and looked like a zombie with his long hair.

Globalization is usually associated with American imperialism, which weakens national and cultural identities. Chadha and Kavoori (2000) and Morley and Robins (1995) thought this approach to be overly simplistic even though it seems to be validated in developing countries, as seen in the rise of foreign programming on television and radio. The pre-Khmer Rouge rock scene looked westward for its influences and musical appropriation, in parallel with the national politic of modernization of the country. The Western cultural reference has changed since the mid 1990s with the rising popularity of Korean pop culture. The Cambodian entrance into postmodernity encompassed two phases. First, the center of reference for cultural identity shifted from the West to Asia. Next, a flow of musical exchange, influences, and appropriation developed among local Cambodians and in the diasporic communities. Through Korean pop music, East and Southeast Asia are turning regionally toward a new identity of shared Asianness.

The Cambodian American diaspora and the new tech-savvy youth are rediscovering their Khmer identity that was disrupted by the Khmer Rouge era and subsequently forgotten. Their music is marked by innova- 
tive hybridization. Modern artists creatively mixed genres like rock-and roll, jazz, Afro-Cuban, and hard rock with a traditional Mohori music style, while postmodern artists combine rap, soul, rock and roll, techno, punk, and hardcore to create unique musical trends.

\section{CONCLUSION}

Cambodian American hip-hop artists are the postmodern artists of today, growing out of their lack of identification with either Cambodia or the United States, as Peter Manuel (1995) states: "Images of the parental homeland may lack experiential referents in the migrants' own lives, while at the same time, migrants may feel alienated from the dominant culture and media discourse of their new homeland" (235). Cambodian Americans, like other migrants, have needed to redefine their social identity and musical tastes within their new home country and in relation to their motherland.

In this era of postmodern collage and global information, music spreads around the world unimpeded, with no need for local interpretation. Regardless of their location, people can now obtain music directly from the original source through social media and internet downloads. A postmodern world has emerged and is recreating its own identity through a fundamental process of cultural appropriation.

As Jencks (2009) writes, "If pure Camembert cheese is modern, then the mixed Cambozola is post-modern and the recent cross breed Camelbert is very pm [postmodern]" (15). Ros Serey Sothea's original song "I'm Sixteen" is the Camembert and Bochan's version is the postmodern mixed breed: postmale, posturban, and postelite. Ros Serey Sothea's song was an early example of appropriation of the Western rock sound combined with local composition. A diasporic Cambodian American brought the song back to America and added another layer of appropriation with her social and political message. And so the circle of musical appropriation and dissemination continues.

The term "appropriation" often has a negative connotation of taking without right, even theft. But appropriation is a necessary and desirable process for cultural advancement. Taking ownership of new cultural identities to create new hybrid forms is integral to all music, creating a universal experience of music that transcends borders.

\section{REFERENCES}

Berman, Marshall. 1998. All That Is Solid Melts Into Air: The Experience of Modernity. London: Penguin.

Butt, John. 2006 "The Postmodern Mindset, Musicology, and the Future of Bach Scholarship." Understanding Bach 1:1-19. 
Chadha, Kalayani, and Anandam Kavoori. 2000. "Media Imperialism Revisited." Media Culture \& Society 22(4):415-32.

Eliot, T. S. "Tradition and the Individual Talent." 1982. Perspecta 19: $36-42$.

Facebook, Inc. No Forever's Facebook page. Accessed April 24, 2014. https://www.facebook.com/noforeverband/info

Facebook, Inc. Show Box's Facebook page. Accessed April 24, 2014. https://www.facebook.com/showboxPP/info

Facebook, Inc. Sliten6ix's Facebook page. Accessed April 24, 2014. https://www.facebook.com/Sliten6ix

Facebook, Inc. The Messenger Band's Facebook page. Accessed April 24, 2014. https://www.facebook.com/pages/The-Messenger-BandCambodia/354978574928?id=354978574928\&sk=info

Giddens, Anthony. 1991. Modernity and Self-Identity: Self and Society in the Late Modern Age. Stanford, CA: Stanford University Press.

Grossberg, Lawrence. 2000. “Is There Rock After Punk?" In On Record: Rock, Pop, and the Written Word, edited by Simon Frith and Andrew Goodwind, 111-124. London: Routledge.

Harvey, David. 1990. The Condition of Postmodernity: An Enquiry into the Origins of Cultural Change. Cambridge, MA: Blackwell.

Jencks, Charles. 2009. "What Then Is Post-Modernism?" In The PostModern Reader, edited by Charles Jencks, 14-17. Sussex, UK: Wiley.

Keo, Narom. 2004. Cambodian Music. Phnom Penh: Reyum.

Ly, Daravuth, and Ingrid Muan, eds. 2001. Cultures of Independence: An Introduction to Cambodian Arts and Culture in the 1950's and 1960's. Phnom Penh: Reyum Institute of Arts and Culture.

Manuel, Peter. 1995. "Music as Symbol, Music as Simulacrum: Postmodern, Pre-modern, and Modern Aesthetics in Subcultural Popular Musics.” Popular Music 14, no. 2;227-239.

Molyka, Rom. 2013. "Cambo Headbanger Strives to Develop Khmer Rock 'n' Roll Scene." Phnom Penh Post, December 18. http://www .phnompenhpost.com/lift/cambo-headbanger-strives-developkhmer-rock-\%E2\%80\%98n\%E2\%80\%99-roll-scene

Morley, David, and Kevin Robins. 1995. Spaces of Identity: Global Media, Electronic Landscapes and Cultural Boundaries London: Routledge, 1995. 
Rogers, Richard A. 2006. "From Cultural Exchange to Transculturation: A Review and Reconceptualization of Cultural Appropriation." Communication Theory 16, no. 4:474-503.

Sam, Ang-Sam. 2002. "Musical Instruments of Cambodia." Senri Ethnological Reports 29. Osaka, Japan: National Museum of Ethnology.

Thompson, Nathan A. N.d. "Punk Rock in Phnom Penh." http://roadsand kingdoms.com/2014/punk-rock-in-phnom-penh/

Thompson, Nathan A. N.d. "Rocking Tradition." Roads and Kingdoms. http://www.slate.com/articles/news_and_politics/roads/2014/01/cam bodia_punk_rockers_the_southeast_asian_country_is_home_to_a_ new_hardcore.html 